\title{
NEW DATA ON KIMBERLITES AND LAMPROITES IN EASTERN KANSAS, U.S.A.
}

\author{
P. Berendsen ${ }^{1}$, R.L. Cullers ${ }^{2}$, A. Barczuk ${ }^{3}$, and A. Al-Ammar ${ }^{4}$ \\ ${ }^{1}$ Kansas Geological Survey, U.S.A.; ${ }^{2}$ Kansas State University, U.S.A.; ${ }^{3}$ University of Warsaw, Poland; ${ }^{4}$ University of \\ Kansas, U.S.A.
}

A cluster of thirteen kimberlites occurs along the trace of the $1.10 \mathrm{Ga}$ NNE-trending Midcontinent Rift System in Riley and Marshall counties in northeastern Kansas (Fig. 1). Three of these were discovered and drilled within the past three years utilizing donated aeromagnetic coverage of the area followed by detailed groundmagnetic surveys. Modeling of the magnetic anomalies shows that final emplacement of the kimberlite bodies is controlled by $\mathrm{N} 40^{\circ} \mathrm{W}$ trending structures, rather than NNE-trending structures and that the contacts between the sides of the kimberlite bodies and the Paleozoic country rock are steeply dipping. The kimberlites are Late Cretaceous (about 90 my) and range from crater and diatreme facies in Riley County to hypabyssal facies in Marshall County.

It is likely that as a result of Cretaceous tectonic activity, strike-slip movement was initiated along NW-SE-trending faults, thus opening pathways for the kimberlites to rise to the surface. Continuous core taken to a depth of $300 \mathrm{ft}$ (91 $\mathrm{m})$ was obtained from each of the three newly discovered kimberlites: Tuttle, Antioch, and Baldwin Creek. Thinsection examination of samples from the Tuttle and Antioch kimberlites show two textural types. The most usual type displays pseudo-detrital (pseudo-conglomeratic), inequigranular texture and contains abundant kimberlite xenoliths, various phenocrysts as well as country rock xenoliths. Kimberlite xenoliths are pelletal lapilli that represent magma droplets typically composed of a thin selvage of kimberlite material surrounding a cognate or exotic clast (Field and Scott-Smith, 1999). The rock can be referred to as an autholithic kimberlite (Dawson, 1980) and typically occurs in the diatreme facies.

The second type displays a more homogeneous, porphyritic texture and consists of a serpentine groundmass containing numerous small, highly altered microphenocrysts. This type does not contain country rock xenoliths and only a few kimberlite xenoliths. The rock is typical of the hypabyssal facies (Field and Scott-Smith, 1999) in the deeper parts of the diatreme.

Phlogopite is the abundant mica, serpentine pseudomorphs after olivine and minor amount of $\mathrm{Cr}$-diopside are the main phenocrysts present. Abundant dark-colored lamprophyretype (micaceous) xenoliths as well as less abundant perodotite/dunite (olivine-rich) kimberlite xenoliths are abundant. Preliminary microprobe analysis show garnet from the Tuttle Creek kimberlite to be pyrope, typically with kelyphitic rims consisting of phyllosilicates and spinel. An unknown (mica-like) mineral having a high barium content also has been identified. Many idiomorph crystals of opaque minerals have a composition typical of ilmenite.

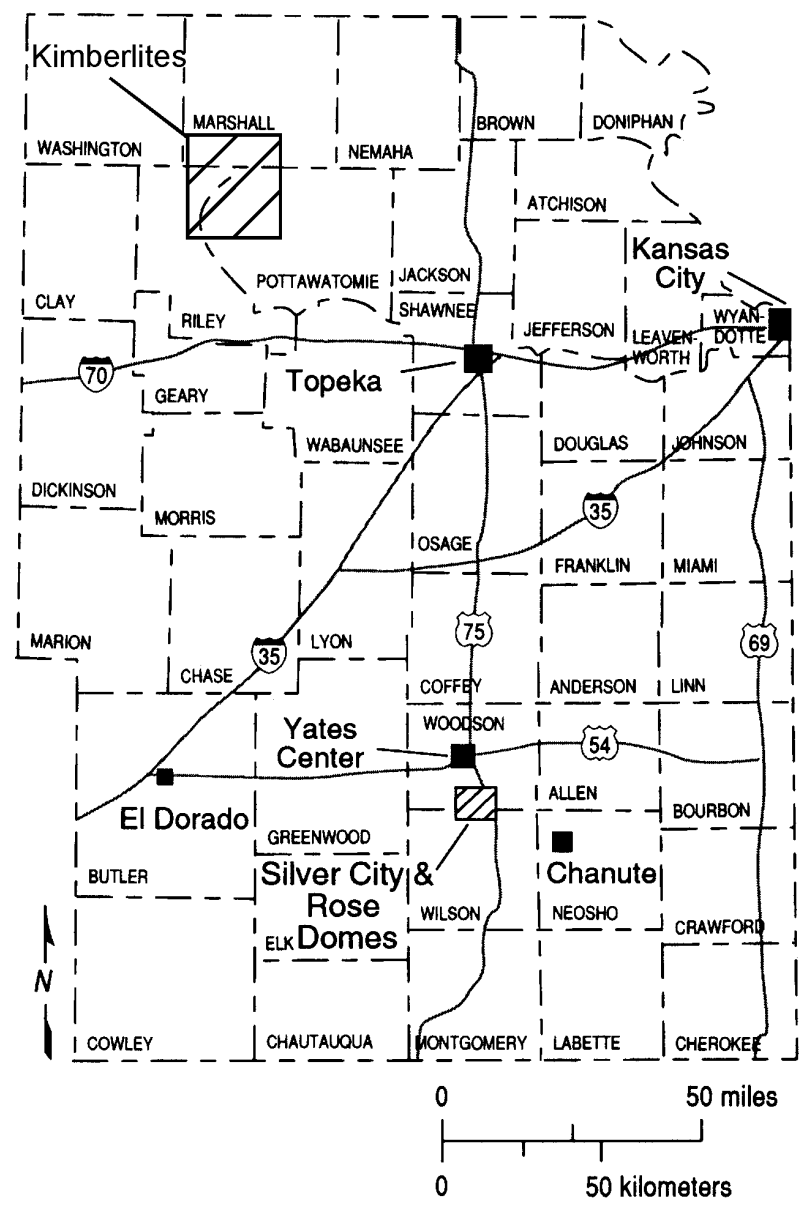

Figure 1. Index map 
Lamproites occur in two locations, at Silver City Dome and Rose Dome, in Woodson and Wilson counties in southeastern Kansas. The name "dome" is actually a misnomer in that it implies a topographic high. Instead the domes are elliptical topographic depressions with their long axis aligned in a NE direction. Both domes are close to $3 \mathrm{mi}$ $(4.8 \mathrm{~km})$ in the long direction, and about $2 \mathrm{mi}(3.2 \mathrm{~km})$ across, and show crater-like morphologies characterized by a central high surrounded by a "moat" having almost complete internal drainage. The domes are surrounded by low, hummocky hills. They are about $3 \mathrm{mi}(4.8 \mathrm{~km})$ apart with the area in between them showing a set of well-defined SW-NE-trending linear ridges. Lamproite is known to be present as a series of shallow dipping sills intruding between alternating layers of shale and limestone units of Middle and Late Pennsylvanian age. In one $800 \mathrm{ft}$ (245 m) deep drillhole in the southern portion of Silver city Dome seven lamproite sills were encountered. As a result of exploration for oil in shale and sandstone of the Cherokee Group of rocks of Middle Pennsylvanian age in and around the domes several tens of drillholes penetrate the section to Mississippian carbonate rocks at about $1300 \mathrm{ft}(400 \mathrm{~m})$. No information about the presence and nature of lamproite below this depth is available. Seismic reflection studies at Silver City Dome failed to demonstrate the presence or absence of lamproite sills in the section, because the contrast in density between lamproite and the enclosing rocks is not sufficient to detect the sills. Gravity and magnetic studies also were unsuccessful. It was hoped that they might shed light on the possible presence of a feeder dike or an intrusive plug at some depth below the Pennsylvanian. The lamproite at Silver City Dome is nonmagnetic, but recent drilling at Rose Dome revealed that the lamproite in two drillholes is magnetic. Drillhole information in the form of core, cuttings, and drillers logs show that lamproite is distributed widely throughout both domes, but the only surface exposures of lamproite are along the northern perimeter of Silver City Dome, where it is being mined commercially by Micro-Lite LLC.

The total thickness of the sedimentary rocks above the crystalline basement is $2,500 \mathrm{ft}(760 \mathrm{~m})$. The basement rocks in the area underlying the domes consist of 1,3501,400 my old rhyolitic volcanic rocks and associated epizonal granitic plutons (Thomas, et al., 1984) belonging to a larger terrane of similar rocks stretching from eastern Missouri through Arkansas into Kansas and Oklahoma.

The Kansas Geological Survey with support and cooperation of Micro-Lite LLC, the owners of the mine and cooperation of landowners has drilled 54 coreholes ranging in depth from less than $30 \mathrm{ft}(9 \mathrm{~m})$ to about $960 \mathrm{ft}(295 \mathrm{~m})$. Most structural and chemical information is based upon closely spaced drilling in the section in which the mine is located. However, valuable information about the distribution and occurrence of sills in other parts of the domes comes from oil exploration drillholes. A well exposed, concentric, high angle fault marks the northern boundary of the dome at the Micro-Lite LLC property. No lamproite is known to occur north of this boundary. Our drilling results have shown that other concentric and radial faults are widespread. Further inspection shows also that most of these faults are reflected in the surface morphology. Using the approach that surface morphology can be used as an indicator of faulting, additional radial and concentric faults can be mapped on and between the two domes. A prominent set of SW-NE-trending linear ridges connecting the two domes probably reflects faulting in the subsurface. Except for the two core holes that we drilled recently at Rose Dome, little subsurface information is available for that area.

The lamproites are ultrapotassic, alkalic, and enriched in mantle-incompatible elements. The fresh rock is dark gray to black, but near the surface the rock weathers easily to a soft honey-brown. The lamproites are porphyritic, consisting of abundant zoned phenocrysts of phlogopite, serpentine pseudomorphs after olivine and less abundant microphenocrysts of potassic richterite, diopside, and chrome spinel set in a groundmass composed mostly of serpentine (Cullers, et al., 1985). No obvious trends are discernable within each sill, with the exception of minor interaction near the top and bottom of each sill. Representative analyses of a sill and the immediately surrounding country rock is given in Table $1 . \mathrm{K}_{2} \mathrm{O}$ and $\mathrm{Al}_{2} \mathrm{O}_{3}$ concentrations are somewhat lower than in other lamproites and also differ between sills in other parts of the dome. The sills are enriched in mantle-incompatible elements.

Rose Dome and Silver City Dome are considered by many workers to be part of a set of eight cryptoexplosive structures closely associated with the $38^{\text {th }}$ parallel (Snyder and Gerdeman, 1965). The age of the lamproite igneous occurrences generally is considered to be Late Cretaceous, which is coeval with the kimberlite igneous occurrences in Riley and Marshall counties in northeastern Kansas. For the last fifty or so years two different theories have been advanced for the formation of Rose and Silver City domes, but not for the kimberlites of the same age. The domes are thought to have been formed either by the impact of a string of bolides derived from the breakup of a larger bolide (Rampino, 1997) or else by explosive ultramafic volcanic activity at or near the intersection of major weak structural zones in the crust. Arguments for an impact include amongst others the presence of shock metamorphic features and breccias. At Rose Dome and Silver City Dome no shock metamorphic features have been recognized. Rounded granitic boulders, ranging in size up to 3-4 ft (0.9$1.2 \mathrm{~m}$ ) in diameter occur at Rose Dome and are concentrated mainly in the area close to the central high of the dome. These granitic boulders have been studied by 
Smith and Franks (1986); we consider them to be clasts ripped from the side of the vent, indicating the violent nature of the explosion. During their transport up the vent, they were subsequently rounded by tumbling action, much like materials that are rounded in a vortex.

Because of the nature of the rocks, the structure exhibited, the morphological characteristics, and the absence of clear indicators associated with impact structures we view the domes as being formed as a result of violent intrusion of volatile magma derived from a deep source and intruded along a crustal zone, or the intersection of zones, of weakness.

\section{REFERENCES}

Cullers, R.L., Dorais, M.J., Berendsen, P., Chaudhuri, S., 1996. Mineralogy and petrology of Cretaceous subsurface lamproite sills, southeastern Kansas, USA. Lithos 38, 185-206.

Dawson, B.J., 1980. Kimberlites and their xenoliths. Springer Verlag, Berlin, Heidelbereg, New York, 252 pp.
Field, M, Scott-Smith, B.H., 1999. Contrasting geology and nearsurface emplacement of kimberlite pipes in southern Africa and Canada. In: Gurney, J.J., Gurney, J.L., Pascoe, M.D., Richardson, S.H. (Eds.), Proc. VIIth Int. Kimberlite Conf., J.B. Dawson Vol. 1, 214-237.

Rampino, M.R, 1997. Defending the crater chain. Geotimes 42(6), 4.

Smith, M.P., Franks, P.C., 1986. Mg-rich sanidine in partially melted granite xenoliths in a mica peridotite at Rose Dome, Woodson County, Kansas. Am. Mineral. 71, 60-67.

Snyder, F.G., Gerdemann, P.E., 1965. Explosive igneous activity along an Illinois-Missouri-Kansas axis. Am. J. Sci. 263, 465493.

Thomas, J.J., Shuster, R.D., Bickford, M.E., 1984. A terrane of 1,350- to 1,400-m.y.-old silicic volcanic and plutonic rocks in the buried Proterozoic of the mid-continent and in the Wet Mountains, Colorado. Geol. Soc. Am. Bull. 95, 1150-1157.

Contact: P. Berendsen, Kansas Geological Survey, University of Kansas, 1930 Constant Ave., Lawrence, KS, U.S.A. 66047.

E-mail: pieterb@kgs.ukans.edu 


\section{TABLE 1}

WHOLE ROCK MAJOR ELEMENT COMPOSITIONS, DRILLHOLE 92-5

\begin{tabular}{lrrrrrrrrrrrrrrrrrrrr} 
Depth [ft.] & 63.7 & 65.1 & 65.3 & 66.1 & 70.5 & 71.7 & 74.8 & 78.2 & 81.6 & 85.6 & 86.1 & 91.5 & 92.4 & 96.1 & 99.8 & 103.6 & 107.1 & 109.4 \\
\hline & & & & & & & & & & & & & & & & & & & & \\
$\mathrm{SiO}_{2}$ & 18.2 & 6.0 & 46.8 & 46.6 & 47.3 & 46.8 & 43.7 & 42.4 & 42.3 & 43.1 & 42.9 & 43.3 & 43.5 & 43.8 & 45.0 & 45.1 & 11.6 & 38.8 \\
$\mathrm{TiO}_{2}$ & 0.032 & 0.020 & 3.08 & 3.17 & 2.63 & 2.56 & 3.24 & 2.83 & 2.38 & 2.87 & 2.81 & 2.74 & 2.59 & 3.32 & 3.22 & 2.99 & 0.011 & 0.668 \\
$\mathrm{Al}_{2} \mathrm{O}_{3}$ & 0.52 & 1.07 & 5.51 & 5.96 & 6.89 & 6.72 & 5.23 & 4.44 & 4.96 & 4.55 & 5.09 & 4.78 & 4.92 & 5.57 & 5.35 & 5.30 & 0.35 & 12.6 \\
$\mathrm{Fe}_{2} \mathrm{O}_{3}$ & 2.75 & 3.94 & 7.43 & 7.81 & 6.65 & 6.48 & 8.06 & 7.88 & 7.28 & 8.04 & 7.58 & 7.43 & 7.46 & 6.80 & 7.79 & 7.35 & 4.22 & 4.71 \\
$\mathrm{MnO}$ & 0.168 & 0.139 & 0.147 & 0.109 & 0.088 & 0.087 & 0.130 & 0.115 & 0.109 & 0.113 & 0.095 & 0.099 & 0.097 & 0.119 & 0.100 & 0.128 & 0.197 & 0.084 \\
$\mathrm{MgO}$ & 2.26 & 3.88 & 13.9 & 15.8 & 15.1 & 15.7 & 17.4 & 19.5 & 19.5 & 21.4 & 19.0 & 18.5 & 20.4 & 11.7 & 18.4 & 17.0 & 3.82 & 7.04 \\
$\mathrm{CaO}$ & 30.4 & 34.1 & 4.07 & 4.01 & 4.78 & 5.10 & 4.96 & 4.35 & 3.16 & 3.63 & 3.35 & 3.70 & 3.38 & 9.63 & 4.46 & 3.49 & 31.0 & 12.3 \\
$\mathrm{Na}_{2} \mathrm{O}$ & 2.74 & 0.201 & 2.56 & 1.97 & 1.82 & 1.70 & 1.41 & 1.84 & 1.69 & 1.89 & 1.83 & 1.63 & 1.61 & 2.59 & 1.85 & 1.69 & 0.93 & 1.29 \\
$\mathrm{~K}_{2} \mathrm{O}$ & 0.392 & 0.238 & 6.19 & 6.09 & 6.82 & 6.90 & 5.19 & 3.66 & 3.94 & 3.62 & 3.93 & 4.08 & 3.89 & 4.87 & 5.06 & 4.70 & 0.202 & 4.38
\end{tabular}

\section{COMPATIBLE TRACE ELEMENT ABUNDANCES (PPM), DRILLHOLE 92-5}

\begin{tabular}{|c|c|c|c|c|c|c|c|c|c|c|c|c|c|c|c|c|c|c|}
\hline Depth & 63.7 & 65.1 & 65.3 & 66.1 & 70.5 & 71.7 & 74.8 & 78.2 & 81.6 & 85.6 & 86.1 & 91.5 & 92.4 & 96.1 & 99.8 & 103.6 & 107.1 & 109.4 \\
\hline Sc ppm & 4.07 & 3.36 & 15.7 & 14.9 & 52.6 & 13.3 & 14.5 & 13.5 & 11.7 & 14.0 & 29.3 & 15.2 & 13.6 & 15.0 & 14.3 & 13.5 & 2.43 & 12.8 \\
\hline V ppm & 342 & 32.3 & 197 & 112 & 77.7 & 56.8 & 87.1 & 49.2 & 38.6 & 40.0 & 35.1 & 89.6 & 58.5 & 121 & 146 & 122 & 18.1 & 113 \\
\hline Cr ppm & 5.76 & 11.76 & 195 & 236 & 351 & 430 & 460 & 395 & 294 & 259 & 293 & 353 & 442 & 216 & 147 & 128 & 6.02 & 111 \\
\hline Co ppm & 2.89 & 5.01 & 42.2 & 44.4 & 46.1 & 42.8 & 49.2 & 52.2 & 53.5 & 52.1 & 47.6 & 50.8 & 53.1 & 37.3 & 44.6 & 46.0 & 2.39 & 14.7 \\
\hline Ni ppm & 19.3 & 25.8 & 524 & 581 & 640 & 578 & 671 & 754 & 825 & 770 & 688 & 771 & 873 & 326 & 620 & 684 & 15.1 & 48.7 \\
\hline $\mathrm{Cu} \mathrm{ppm}$ & 6.73 & 10.7 & 58.5 & 63.3 & 52.4 & 36.6 & 58.7 & 56.5 & 49.6 & 51.8 & 55.9 & 56.3 & 51.4 & 65.7 & 64.8 & 42.5 & 2.30 & 15.0 \\
\hline Zn ppm & 6.62 & 20.2 & 70.4 & 80.0 & 59.0 & 62.7 & 156 & 87.5 & 72.0 & 75.8 & 93.2 & 75.8 & 74.4 & 69.3 & 76.1 & 75.5 & 5.2 & 65.9 \\
\hline
\end{tabular}

